World Lumen Congress 2021 | May 26-30, 2021 | lasi, Romania

\title{
Integrated Care for Seniors as a Challenge for Slovakia
}

\author{
Michaela VACEKOVÁ, Jana LEVICKÁ \\ https://doi.org/10.18662/wlc2021/70
}

How to cite: Vaceková, M., \& Levická, J. (2021). Integrated Care for Seniors as a Challenge for Slovakia. In A. Sandu (vol. ed.), Lumen Proceedings: Vol. 17 World Lumen Congress 2021 (pp. 689-705). Iasi, Romania: LUMEN Publishing House. https://doi.org/10.18662/wlc2021/70 


\title{
Integrated Care for Seniors as a Challenge for Slovakia
}

\author{
Michaela VACEKOVÁ1, Jana LEVICKÁ²
}

Abstract

Older age can be accompanied by a lot of changes in the field of health, which influence the social functioning of seniors. One of the factors influencing the quality of life of seniors is the connection of bealthcare and social care, built on the interdepartmental cooperation. This approach is still absent in Slovakia. The aim of the paper is therefore to emphasize the importance and need of integrated care and to describe the barriers that prevent its implementation in Slovakia. In search of answers to the questions: "When and why was the healthcare and social care department of seniors established in Slovakia? What are the reasons persisting in this condition? What are the consequences of this divided care for the seniors in practice? What strategies use facilities for seniors to overcome this situation during the COVID-19 pandemic?" the authors used the method of the case study (Yin, 2003) focused on the Trnava self-governing region. Persistent structural, procedural, legislative and political factors have been identified as the main barriers. Specific for Slovakia is the existence of a barrier of the profession, which is caused by the low interest of social workers in the issue. The authors state that the situation in Slovakia is caused mainly by the reflection of integrated care as a political problem. In the end, the authors make several suggestions for solving the situation.

Keywords: Integrated care, case study, social work, seniors.

\section{Introduction}

Demographic ageing is a long-term global trend. Briggs et al. (2018) estimate that the share of the global population aged 60 years and over will increase almost double in between 2015 to 2050, and point out that the best possible preparation for this situation is needed. Slovakia, which is one of the countries with the fastest ageing of the population in the EU, must also

\footnotetext{
${ }^{1}$ Mgr., Department of Social Services and Counselling, Faculty of Social Sciences, University of Ss. Cyril and Methodius in Trnava, Slovakia, vacekovam@gmail.com

2 Prof. PhDr. Mgr., PhD., Department of Social Services and Counselling, Faculty of Social Sciences, University of Ss. Cyril and Methodius in Trnava, Slovakia, j.levicka@,centrum.sk
} 
prepare for the situation, which results in increasing demand for social services and, in particular, long-term care (LTC) services.

We focus our attention on the target group of seniors, who are currently the most at risk group in the field of social work and social services due the growing trend of ageing of the population. It must not be forgotten that they are an equally important part of society and therefore it is necessary to ensure health and quality ageing. The ageing of the population brings with it a number of chronic and neurodegenerative diseases, which at the same time causes a greater demand for quality LTC and quality provision of social services. Older age is usually accompanied by a combination of health problems, which in turn affect the social functioning of seniors. Thus, a wide range of needs must be satisfied for the elderly population in the longterm, and it is in view of this fact that long-term integrated care for the elderly is very important (Cangár \& Machajdíková, 2017). Levická et al. (2009) point to the fact that a multidisciplinary team and interdepartmental cooperation in the field of care for elderly people is a necessary attribute for the provision of quality and professional care. We consider all these reasons to be key stimuli for the solution to the systemic change and setting up of long-term integrated care, which is still absent in Slovakia.

\section{Integrated Care in the Context of Long-Term Care in Slovakia}

According to Kodner and Spreeuwenberg (2002, In: Repková, 2011) integrated care represents a comprehensive set of methods and models for creating cooperation in financing, administrative and organizational support and provision of healthcare and social services to support the quality of care and quality of life recipients of services. Integrated care is also a system solution with higher effectivity. At present, integrated care is significantly associated with LTC.

The OECD (2020) defines LTC as a set of person-oriented services (health and social), who is dependence on the assistance of another person in activities of daily living. LTC is associated primarily with target groups of seniors and people with disabilities (Repková, 2011; Cangár, Machajdíková, 2017 , etc.). It is true that when we are working with seniors, we feel the need for integrated care the most intense. However, WHO presents integrated care as a managed system of services aimed at providing ongoing health promotion, disease prevention, diagnosis, treatment, disease management, rehabilitation and palliative care, coordinated at different levels and places of care within healthcare. The WHO emphasizes that coordinated care does not only focus on the age group, but it is care for people based on their 
lifelong needs. However, integrated care understood in this way concerns the integration of care into the health care system. In relation to seniors, was developed under the auspices of the WHO, the concept of Integrated Care for Older People (ICOPE), which promotes the interconnection of healthcare and social care (Briggs et al., 2018).

Currently in Slovakia is long-term integrated care one of the most serious problems in the field of care for the chronically ill people and for the elderly, while the need for its implementation in practice has been discussed in Slovakia for more than 20 years. Unfortunately, although a draft law about integrated care is currently being prepared and several strategic documents have been developed, we still do not see a real solution to this issue on a practical level. For this reason, we consider integrated care as a challenge for Slovakia and at the same time we feel the need for a real solution to this issue in practice.

\subsection{Reasons of the persistence of divided social care and healthcare in Slovakia}

Several authors such as Andersson et al. (2011); Threapleton et al. (2017); Hugges (2017) in their scientific publication write about integrated care and barriers in its implementation in practice. Repková et al. (2011) also define several basic barriers that hinder the implementation of integrated care which are also characteristic for Slovakia:

- Structural barriers (distribution of competencies between specific departments),

- Procedural barriers (diverse and uncoordinated sectoral competencies in the field of LTC),

- Issues of status and legitimacy (unequal status of healthcare and social care, public providers and non-public providers, etc.),

- Financial barriers (insufficient funds are not allocated for problems, lack of perception of the seriousness of the problem, the issue of availability of social services).

We also consider political and legislative factors to be significant barriers in the implementation of integrated care in Slovakia. This situation in Slovakia is caused mainly by the reflection of integrated care as a political problem. Perception of integrated care as a political problem is also supported by publications by authors in the field of healthcare, who perceive it as a tool for economic savings in the sector and not as a tool for improving the quality of life of seniors. Due to the fact that there is still no legislative support for long-term integrated care, it is not possible to 
effectively implement this care in practice. Another important barrier in connection with the implementation of integrated care in Slovakia is also considered the low interest and minimal involvement of social workers in solving the issue of integrated social and healthcare. Due to the impact of insufficient interest of social workers in the issue of integrated care, we identified it as a barrier of the profession. The connection with the profession signals that this may be a consequence of the insufficiently understood role of social work in this field. If the low interest of social workers in the issue of integrated care persists, this situation will remain only under the auspices of the Ministry of Health. The Ministry of Health in its concepts does not show interest in the field of social services and other services supporting the care of the elderly in their natural environment.

Slovakia has long time divided human care among several departments. Healthcare belonged to the Ministry of Health and care for social services and social and legal protection belonged to the Ministry of Labour, Social Affairs and Family. Other issues were addressed by other ministries. Each ministry had its own competencies set and their mutual respect was the basis of cooperation. However, the financing of general care was centrally provided from public sources, which also meant that nurses worked in social care facilities and provided clients nursing care. The transition to a democratic system of governance of the country (after year 1990) began a period of regular rotation of governments and frequent rotation of individual ministers as well as experts in ministries. Although in connection with the political development in Slovakia after year 1990, it is not possible to speak of political instability in the true sense of the word, this rotation of governments did not contribute to the necessary consolidation of the whole system.

In addition, the period of decentralization of state administration has begun, which has pushed back the search for common solutions to the issue of social care and healthcare. And although the need to create a systemic connection between the ministries (Ministry of Health of the Slovak Republic and the Ministry of Labour, Social Affairs and Family of the Slovak Republic) began to be discussed immediately after 1990, this idea did not realize.

In the Slovak Republic, social care and healthcare still represent two separate systems with minimal cooperation. It is insufficient connection of these two areas of care that brings with it a number of problems in practice. At the economic level, the healthcare system is covered by health insurance companies, which reimburse only the services associated with the necessary health care. Health insurance companies have long refused to admit that social services facilities and especially facilities for the elderly provide 
healthcare services and therefore did not provide them with any financial compensation for these services. The growing number of clients who have expressed an interest in social services in facilities for the elderly has caused the Ministry of Labour, Social Affairs and Family of the Slovak Republic to recommend facilities for the elderly to accept only applicants who have been granted IV. or V. degree of reliance on the assistance of another person. In practice, this recommendation means that to facilities for the elderly are admitted clients with a high degree of independence, requiring social care and demanding healthcare.

Existing legislation currently acts as one of the major barriers to creating a new systemic connection between healthcare and social care. The initial understanding of the WHO or OECD integrated care as a system of internal integration of the healthcare system, on which the Ministry of Health of the Slovak Republic focuses primarily, also contributed to the persistence of the situation.

Another obstacle is the fact that if integrated care is to emerge, it needs to be a joint result of intensive cooperation between the Ministry of Health and the Ministry of Labour, Social Affairs and Family of the Slovak Republic. Joint work would open the door to assess the implementation of other models of integrated care, which more reflect not only the approach of healthcare or social work to the scoring of this care, but would also reflect the needs of seniors. One of the appropriate approaches is the Chronic Care Model (CCM), which connections community social care with health services (Uittenbroek et al., 2017; Wagner et al., 2001; Boyd et al., 2007).

Such an outcome can be expected if the individual political representations are ready for consensus. Integrated care will really emerge if both line ministries follow the idea of creating a useful and effective system of long-term care and leave the promotion of the interests of their political orientation. Also within the last strategic plan Strategy of long-term social and healthcare in Slovak Republic (2019), which builds on the material from 2015 prepared by the Institute of Health Policy of the Ministry of Health of the Slovak Republic and in which partially participated the Ministry of Labour, Social Affairs and Family, we again note insufficient cooperation (Levyová et al, 2019).

On the $28^{\text {th }}$ April 2021, the Government of the Slovak Republic issued the Program Statement of the Government of the Slovak Republic for the period 2021 - 2024, in which one of the priorities is the necessary reform of LTC. It is a program statement of the reconstructed government after overcoming the government crisis. The Government of the Slovak Republic undertakes to prepare new legislation on long-term care, which will focus on addressing comprehensive health care, social care and nursing care (Program Statement 
of the Government of the Slovak Republic, 2021 - 2024, p. 39). Persistent problems within the governing coalition signal that the drafting and adoption of the necessary legislation is still threatened, as the individual ministries are currently governed by the political representations of two different coalition partners. Although it seems that the ministries are really cooperating, the fact is that while Ministry of Health of the Slovak Republic is preparing health and social care, the Ministry of Labour, Social Affairs and Family of the Slovak Republic discussion about social and healthcare.

\subsection{Strategies used by facilities for seniors during the COVID-19 pandemic to overcome divided social care and healthcare for seniors}

The narrowly focused approach to care for seniors was manifested mainly in social services facilities, which in the Slovak Republic fall under the competence of the Ministry of Labour, Social Affairs and Family of the Slovak Republic. This is exactly what the facilities for the elderly felt. For older clients it is characteristic polymorbidity and in the age category over 80 years to multimorbidity (Birggs et al., 2018). This fact requires that quality healthcare, especially nursing care, is also provided in facilities for the elderly. Services related to health care in the Slovak Republic are reimbursed through health insurance companies, which accumulate funds through compulsory health insurance. It was health insurance companies that have long refused to finance services related to healthcare provided in facilities for the elderly (Levická et al., 2015). It was not until 2018 that the approach of health insurance companies changed, when the Ministry of Health of the Slovak Republic issued Decree No. 92/2018, by which it determined the conditions necessary for the performance of qualified medical staff working in the facilities of the Ministry of Labour, Social Affairs and Family of the Slovak Republic to be financed from health insurances. The decree precisely defines the number of medical procedures (9) that can be financed from these sources.

Paradox, a major shift in the return of cooperation between the Ministry of Health and the Ministry of Labour, Social Affair and Family was the COVID-19 pandemic, which "helped" significant cooperation in the creation of intervention teams. During the COVID-19 pandemic, both ministries agreed to set up intervention teams whose members included doctors, nurses and other experts. These teams were assigned to individual social services facilities in which COVID-19 was confirmed. The role of the intervention teams of the Ministry of Health of the Slovak Republic was to control the healthcare of clients in social services facilities in order to assess their accuracy in the context of the latest knowledge of compliance with 
hygiene measures needed to stop the spread of COVID-19 in facilities and to mediate the latest approaches from nursing care (Ministry of Health of the Slovak Republic, 2020). The need to fight the pandemic thus united the two ministries.

Incorrect understanding of the activities and functioning of comprehensive care in social services facilities, and thus also in facilities for the elderly, has led to the long-term underestimation of these facilities in terms of personnel. Personal security in social services facilities is governed by the applicable legislation (Act No. 448/2008 on social services), which allows the possibility that it would be necessary to provide this care with a higher number of staff, but contributes financially only to a minimum standard. This fact does not allow the so-called increase the number of employees by public providers.

During the COVID-19 pandemic, this problem resonated significantly. The reason was not only the increasing number of clients ill at COVID-19 and the increasing complexity of care, but also the number of employees who, due to their own illness or for other reasons, had to join the so-called pandemic incapacity for work or pandemic nursing care for a family member.

From the level of the Ministry of Labour, Social Affairs and Family of the Slovak Republic (2020) was initiated the preparation and signing of a Memorandum of Cooperation, the aim of which was to mobilize students volunteers, some of whom studied from social work programs, to perform volunteering in facilities affected by COVID-19 disease. Our Faculty is one of 11 faculties of Slovak universities that signed the memorandum and the students actively helped in the social services facilities. Our students also participated in work in the centers where testing for COVID-19 disease. Naturally, the social services facilities also activated those volunteers with whom they had worked before the pandemic (Imrovič, 2021).

Within the Trnava self-governing region (TSGR), the self-governing region, which is the founder of several social services facilities and contributes financially to the functioning of social services provided by nonpublic providers, also began to organize voluntary personnel assistance between facilities that are within the founding powers of the TSGR. The employees of these facilities were released at their own workplace and went to work for 5-10 days in social services facilities, which were quarantined due to the spread of COVID-19. The closure of the facility was preceded by the adoption of a pandemic plan, which envisages the division of staff into at least 2 groups, one of which remains in quarantine with clients and the other group as a backup to be ready to replace those staff who were in the closed 
facility. In such a regime, every single person who was willing to come to work in a quarantine facility and strengthen the staff was extremely valuable.

\section{Methodology}

The aim of the paper is to answer the question: How is it possible that Slovakia still lacks an integrated care? Given this goal, we decided to use the design of the case study (Yin, 2003). The advantage of the case study is that it allows to capture the investigated problem in the natural conditions of the case (Švaŕíček, Šed'ová et al., 2014; Creswell, 2007). Yin (2003) among the variants that the case study can acquire also mentions its illustrative variant, when the investigated problem is evaluated in a descriptive way. It is this way of capturing the situation in the Slovak Republic that seems to us to be the most suitable.

In the realization of the case study, we used standard methods of social reality research, which were content analysis of written sources (study of relevant literature, current legislation, strategic documents of the TSGR, statistical data of the Statistical Office of the Slovak Republic, etc.) and semistructured interviews with independent local expert, analyst, who has been participating in the creation of strategic documents for the field of social care of the TSGR for more than 10 years.

\section{Case study focused on the Trnava self-governing region}

The situations that facilities for the elderly had to face during the pandemic even more urgently pointed to the need for coordination of care between the ministries (Ministry of Labour, Social Affairs and Family of the Slovak Republic and Ministry of Health of the Slovak Republic). It also showed that the exceptional situation led to cooperation at all levels of the country's functioning.

We are currently in a period of relative peace. The pandemic in Slovakia is declining. However, experts are already warning against the onset of the third wave of the pandemic. An indirect consequence of the pandemic is also the deterioration of the health status of the elderly, where we record, also an increase in mental illness, especially depression. This fact leads us again to focus more intensively on integrated care.

We want to illustrate the importance of this solution on the example of the situation in TSGR. TSGR is a self-governing body whose competence extends to the districts of Trnava, Dunajská Streda, Galanta, Hlohovec, Piešt'any, Skalica and Senica. It is a region with 564,917 inhabitants. From a 
demographic point of view, TSGR is the fastest ageing self-governing region in the Slovak Republic. We consider the ageing index to be an important demographic data, which for TSGR as of 31.12. 2019 was set at 117.92 points. At the same time, the average age of the population was almost 42 years. Within the region, however, we find significantly different values in the districts, while the fastest ageing population is in the district of Piešt'any, where the aging index was at the level of 147.22 points. The total population of TSGR as of 31 December 2019 was 564,917 inhabitants. Of this, 89,414 people were over the age of 65 , representing $15.82 \%$. We compared this figure with 2014, when the total population was 558,677 and over 65 years of age lived in TSGR 80,188 inhabitants, which represented $14.35 \%$ of the region's population. At the end of 2019, there was an increase of 9,226 people over the age of 65 , which represents an increase of $1.47 \%$ (Statistical Office of the Slovak Republic, 2020; Statistical Products and Services Provision Section, 2016).

Social care provided within the TSGR copies the overall situation in Slovakia, where care provided in facilities for the elderly dominates in the provision of LTC for seniors. Although the care provided in the client's home environment (home care service) has a long tradition in the Slovak Republic, it is even more undersized in terms of personnel and finances than care provided in social services facilities. The aim of this service is to provide assistance in the field of personal or residential hygiene of clients, provision of food and social contacts. If the health condition of a senior is acutely deteriorated, his family can also use home nursing agencies, which, however, is already a health service. This service is intended for patients who need professional nursing or rehabilitation care. As part of home nursing care, there is no available record of carers at the regional or national level. In our paper, therefore, we provide an up-to-date overview of providers and recipients of social services in TSGR, especially in residential facilities. The number of clients in facilities for the elderly ranges in between $40-120$ social service recipients. Older social services facilities have a higher capacity and facilities that have been established in the last 10 years cannot have a capacity higher than 40 recipients of social services (Act No. 448/2008 on social services).

As of 30.09.2020, 208 social service providers with a total capacity of 7858 social service recipients were registered in the TSGR territory.

Facilities for seniors are given priority to seniors who rely on the provision of social services. In recent years, TSGR has also been developing day hospitals for the elderly as well as social services provided in specialized facilities. Within the Trnava region, we recorded an increase in capacity in facilities for the elderly by $79.9 \%$ in $2009-2019$. 


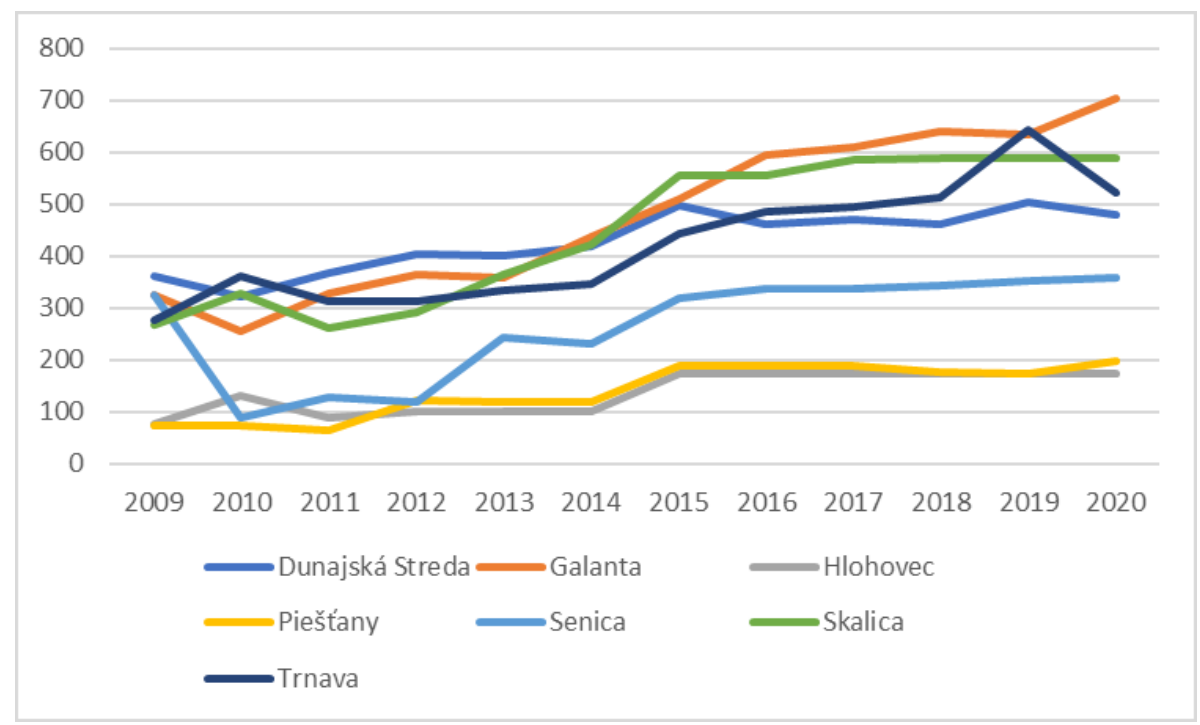

Figure 1. Development of capacities in social services facilities in TSGR in $2009-2019$

Specifically, in TSGR are 55 providers who provide services in facilities for the elderly with a total capacity of 3022 recipients of social services. Public providers (former state-established facilities) and non-public providers are involved in providing this care.

Given the demographic situation in TSGR (the fastest ageing region), it is reasonable to assume that the number of seniors dependent on some type of social service will increase permanently and therefore it will be necessary to increase the number of facilities for the elderly and strengthen the development of other types of social services to cover these needs. At the same time, it is the field of social services that is of interest to non-public providers who are building new facilities for the elderly in TSGR. The following figure shows that the number of public and non-public social service providers in facilities for the elderly in TSGR is almost balanced. 


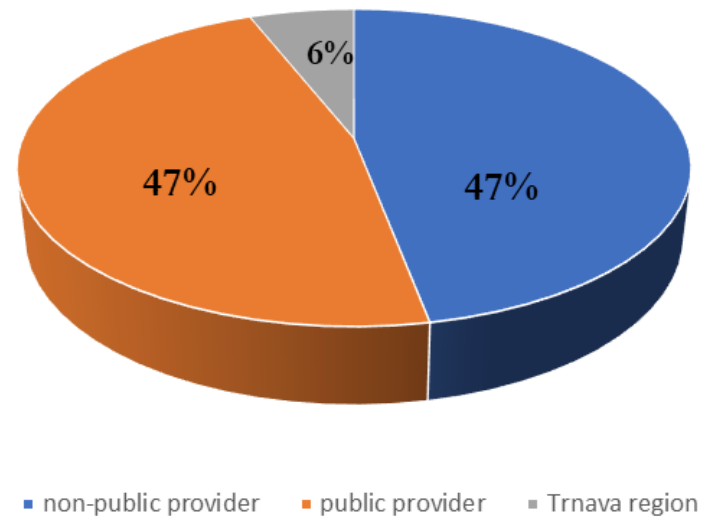

Figure 2. Percentage proportion of social service providers in facilities for the elderly as of 30.09 .2020

Part of social services is also provided to seniors in specialized facilities. Specialized facilities are facilities providing care for people with psychiatric diagnoses such as various types of dementia, Alzheimer's disease, Parkinson's disease, etc. At the same time, these are social services, which are very demanding on material equipment, staffing and thus on the financial coverage of this service. Although these diseases mainly affect the elderly, their recipients are also younger individuals.

It is the complexity of the establishment and operation of the specialized facilities that is the reason why the municipalities and cities of TSGR are not involved in the construction of these facilities. This can be seen from the data in figure no. 3. To $61 \%$ of specialized facilities providers are in the founding competence of TSGR. The founders in the remaining $39 \%$ are non-public providers. 


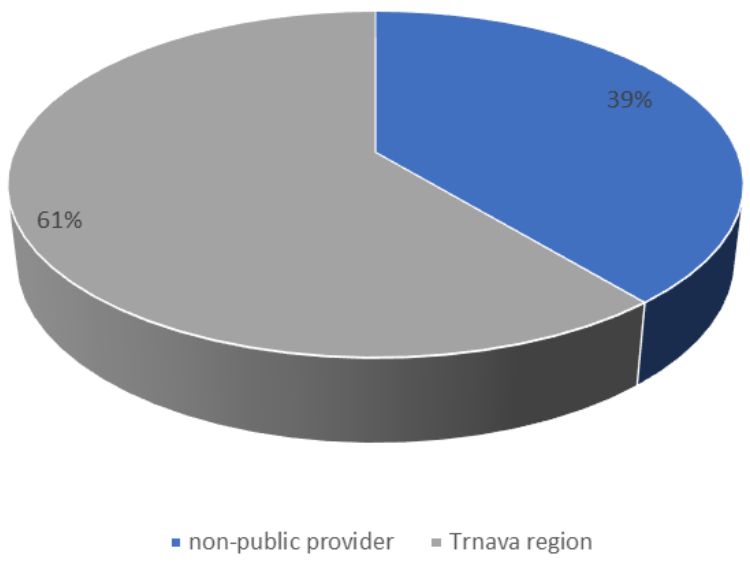

Figure 3. Percentage proportion of social service providers in specialized facilities as of 30.09 .2020

Despite these facts, TSGR registry a relatively high number of applicants for the provision of year-round service in the social services facilities.

Table 1. Registry of applicants for social service in waiting list TSGR

\begin{tabular}{lc}
\hline Type of facility & Number of applicants of social service \\
\hline Social services homes & 392 \\
Facilities for the elderly & 219 \\
Specialized facilities & 247 \\
Registry of applicants for & $\mathbf{8 5 8}$ \\
social service together & \\
\hline
\end{tabular}

As we can see in table no. 1, TSGR currently registers 858 applicants for social service, which means that the capacity of existing facilities is not sufficient.

At TSGR, non-public care providers in facilities for the elderly are experimenting with different degrees of linking social care and healthcare for the elderly in order to provide them with the most comprehensive care possible. This is made possible by the fact that, in addition to the state 
subsidy, non-public providers also receive income from clients for the provision of care, which is an order of magnitude higher than the monthly payments of seniors in facilities for the elderly, which are among the public providers. Another factor that allows non-public providers to link health care and social care is a certain legislative freedom, which does not prohibit other types of care to exist in one building in addition to social services.

Public providers in the area of facilities for the elderly cannot use this possibility precisely because they are set up by self-governing bodies, the structure of which copies the structure of ministries and thus have separate sections of health care and social care.

The amount of the monthly fee for the provision of social services in a facility for the elderly at a public provider is strictly set, while the legislation protects the income of a senior so that $25 \%$ of his pension remains after payment for payment for the provision of services in the facility for the elderly. In facilities set up by public providers, the number of seniors who receive very low old-age pensions is thus increasing, which worsens the financial condition of these facilities.

Despite this fact, TSGR in its strategic documents (Concept of Social Services Development in the territory of TSGR and the Plan of economic development and social development) prepared for the period 2022-2030, plans with the introduction of integrated care. With this step, the TSGR responds to important human rights documents as well as to EU documents and standards, which are binding for Slovakia as a member state. TSGR thus responds to the fact that multimorbidity occurs mainly in those seniors who are socio-economically deprived (Briggs et al., 2018). In its approach, TSGR expands the understanding of integrated care to include the aspect of economic responsibility. It is the social services provided by facilities for the elderly, the founder of which is TSGR, that are the most economically advantageous in the entire Trnava region. These facilities accept not only clients with very low pensions, but also with a very complicated state of health. This situation directly requires TSGR to plan future development in the field of care in such a way that it is able to ensure access to all types of care and at the same time ensure the required quality of social and health services.

\section{Conclusion}

The aim of the paper was to emphasize the importance and need for integrated care and to describe the barriers that prevent its implementation in Slovakia. In the case study focused on Trnava self-governing region 
(TSGR), the authors emphasized the need for the necessary systemic change and implementation a long-term integrated care in Slovakia, the need of which experts have been talking about for more than 20 years. Despite their long-term efforts to implement integrated care in Slovakia, a real solution to the issue has not yet come in practice. We consider long-term integrated care to be an important component in addressing the challenges of an ageing population. Given that Slovakia is the fastest ageing EU country and the demand for social services for the elderly is growing, we consider a systematic change and implementation of long-term integrated care to be necessary for the improvement and streamlining of social and healthcare services. The case study, which was focused on TSGR, is illustrative in order to point out the situation in the field of care for the elderly in Slovakia. The numbers of seniors waiting to enter year-round care in facilities for the elderly in individual regions of the Slovak Republic are different, but the common feature is the fact that in recent years only those applicants who belong to the group of highly endangered clients are admitted to these facilities. The increasing average age of the population of the Slovak Republic, the lack of capacity in year-round facilities for the elderly and insufficiently developed community services are not only a worrying situation, but also a motive for the modernization of services focused on people. By preparing and introducing integrated care, connecting healthcare and social care into one system, which will significantly contribute to the quality of life of seniors, the Slovak Republic would not only improve care for the elderly, but also fulfill its obligations to the EU, which considers integrated care necessary to maintain the social protection system. Several Slovak and foreign authors, on whom we base our claims, point out the importance of introducing a functional system of long-term integrated care adapted to the needs of individual countries. Authors Levická, Repková, Cangár and Machajdíková deal with long-term care in Slovakia. From foreign authors, we relied on the scientific research findings of several authors for example Hugges, Briggs, etc. At the same time, we also find support and the importance of integrated care in the WHO definitions. In the article, we pointed out several significant barriers that prevent the implementation of integrated care in Slovakia. We consider the most important barrier to be the lack of legislative support for the given issue, which could mean the first step towards a real solution to the setting up of a long-term integrated care in Slovakia. The biggest challenge for social workers is the barrier of the social work profession. The very lack of interest and minimal involvement of social workers in the solution of social and health care contributes to the persistence of this situation and the long-term non-solution of the problem. We are convinced that by publishing 
contributions focused on issues related to integrated care issues and pointing out its need, we can achieve an increased interest in its real solution in practice. In the search for a suitable solution, Slovakia can be inspired by countries in which the introduction of integrated care has led to an improvement and streamlining of social and healthcare. At the same time, our contribution could be an inspiration for countries that are similar to Slovakia and have not sufficiently addressed the issue of integrated care. We consider international support and the exchange of interdisciplinary expertise and experience to be important in the context of progress in this area. In the future, we want to continue to address the issue of long-term integrated care and bring new findings and possible solutions in this field of scientific research.

\section{Acknowledgement}

This paper was supported by the project: Working methods and procedures of social workers in facilities for seniors with number FPPV-08-2021 and by the Operational Program Integrated Infrastructure for the project: Addressing societal threats due to the COVID-19 pandemic, Code ITMS2014+: 313010ASN4, co-financed by the European Regional Development Fund.

\section{References}

Act No. 448/2008 on social services.

Andersson, J., Ahgren B., Bihari Axelsson S., Eriksson, A., \& Axelsson, R. (2011). Organizational approaches to collaboration in vocational rehabilitation An international literature review. International Journal of Integrated Care, 11(4). http://doi.org/10.5334/ijic.670

Boyd, C. M., Boult, C., Shadmi, E., et al. (2007). Guided care for multimorbid older adults. Gerontologist, 47(5), 697-704. https://doi.org/10.1093/geront/47.5.697

Briggs, A. M., Valentijn, P. P., Thiyagarajan, J. A., \& de Caevalho, I. A. (2018). Elements of integrated care approaches for older people a review of reviews. BMJ Open, 8(4). https://doi.org/10.1136/bmjopen-2017-021194

Cangár, M. \& Machajdíková, M. (2017). Dlbodobá starostlivost'v Slovenskej republike. Potreba systémovej żmeny. 28 p. https://www.rpsp.eu/wpcontent/uploads/2018/04/LTCpolicybrief final.pdf

Creswell, J. W. (2007). Qualitative Inquiry \& Research design. Choosing Among Five Approaches. Second Edition. Thousand Oaks: SAGE.

Decree of the Ministry of Health of the Slovak Republic No. 92/2018. 
Threapleton, D.E., Chung, R.Y., Wong, S.Y.S., Wong, E., Chau, P., Woo, J., Chung, V.C.H., Yeoh, E.-K. (2017). Integrated care for older populations and its implementation facilitators and barriers: A rapid scoping review. International Journal for Quality in Health Care, 29(3), 327-334. https://doi.org/10.1093/intqhe/mzx041

Hugges, G. (2017). New models of care: the policy discourse of integrated care Gemma Hughes. People, Place and Policy, 11(2), 72-89. https://doi.org/10.3351/ppp.2017.6792867782

Imrovič, M. (2021). Volunteering and volunteer activities of students during the COVID-19 pandemic in Slovakia. In: Bočáková, O., Levická, J. \& Draková, Z. (eds.). COVID-19 Pandemic in the European region (scientific studies). Brno: Tribun EU, 40-47.

Levická, J., et al. (2009). Sociálna práca II. Trnava: Oliva.

Levická, J., et al. (2015). Identita slovenskej sociálnej práce. Trnava: Typi Universitatis Tyrnaviensis; VEDA.

Levyová, M., et al. (2019). Strategy of long-term social and bealth care in Slovak Republic. https://www.health.gov.sk/Clanok?strategia-dlhodobej-socialnozdravotnej-starostlivosti-v-sr

Ministry of Labour, Social Affairs and Family of the Slovak Republic. (2020). 11 fakúlt vysokých škôl a ministerstvo sa pryjkerát stali partnermi pre spoluprácu v zariadeniach sociálnych sluřieb.

https://www.employment.gov.sk/sk/informacie-media/aktuality/11fakult-vysokych-skol-ministerstvo-prvykrat-stali-partnermi-spolupracuzariadeniach-socialnych-sluzieb-case-mim.html

Ministry of Health of the Slovak Republic. (2019). Stratégia dlhodobej sociálno-zdravotnej starostlivosti v Slovenskej republike.

https://www.health.gov.sk/Clanok?strategia-dlhodobej-socialnozdravotnej-starostlivosti-v-sr

Ministry of Health of the Slovak Republic. (2020). COVID-19: V teréne poskytujú pomoc intervenćné timy. https://www.health.gov.sk/Clanok?covid-19-13-102020-timy-intervencne

Organisation for Economic Co-operation and Development (OECD). (2020). OECD Health Statistics 2020 - Definitions, Sources and Methods.

Program Statement of the Government of the Slovak Republic for the period 2021 - 2024. (2021).

https://www.nrsr.sk/web/Dynamic/DocumentPreview.aspx?DocID=494 $\underline{677}$

Repková, K. (2011). Dlhodobá starostlivost'v kontexte integrovanej sociálnej práce. Bratislava: IVPR.

Repková, K., a kol. (2011). Dlhodobá starostlivost' o staršich l'udí na Slovensku a v Európe (3). Správa, riadenie a financovanie. Bratislava: IVPR. 
Statistical Office of the Slovak Republic. (2020).

https://slovak.statistics.sk/wps/portal/ext/home/!ut/p/z1/hY7LDoIwE

EW_hQVbOqQg1V01hkeIEaIRuzFgEDDQklLh923UhQsfs7tzz5kMYih

DjOdjU-

WqETxvdT6y2SnxQrJc2hTIJ11DuKNbP40cGxwXHf4BTNfwZShonz2Q1 U8Dx4sBSOy7ENJgn84TjIHiF_DjRoRY1Yri-

S71BSYVYrK81LKU1k3qda1UPyxMMGGaJqtoeGWdRWfCJ6EWg0LZO 4f6LoOr244xNYw7xYwiZg!!/dz/d5/L2dBISEvZ0FBIS9nQSEh/

Statistical Products and Services Provision Section. (2016). Trnavsky kraj in figures.

Švaříček, R., Šed’ová, K., et al. (2014). Kvalitativni výzłłum v pedagogických védách. Praha : Portál.

Trnava self-governing region (TSGR). Koncepcia rozvoja sociálnych služieb na území Trmavskébo samosprávneho kraja 2021-2023. https://www.trnavavuc.sk/data/att/18214.pdf

Trnava self-governing region (TSGR). Vstupná Správa pre vypracovanie PHRSR TTSK 2022 - 2030. https://www.trnava-vuc.sk/data/att/18260.pdf

Uittenbroek, R. J., Kremer, H. P. H, Spoorenberg, S. L. W. \& Reijneveld, K. W. (2017). Integrated Care for Older Adults Improves Perceived Quality of Care: Results of a Randomized Controlled Trial of Embrace. J Gen Intern Med., 32(5), 516-523. https://doi.org/10.1007/s11606-016-3742-y

Wagner, E.H., Austin, B.T., Davis, C., Hindmarsh, M., Schaefer, J., \& Bonomi, A. (2001). Improving chronic illness care: translating evidence into action. Health Aff (Millwood), 20(6), 64-78. https://doi.org/10.1377/hlthaff.20.6.64

World Health Organization (WHO). (2016). Framework on integrated, people-centred bealth services. Geneva.

https://apps.who.int/gb/ebwha/pdf_files/WHA69/A69_39-

en.pdf?ua $=1 \& u a=1$

World Health Organization (WHO). (2016). Integrated care models: an overview. https://www.euro.who.int/_data/assets/pdf_file/0005/322475/Integrat ed-care-models-overview.pdf

Yin, K. R. (2003). Case Study Research: Design and Methods. 3th edition. London: SAGE Publications. 